\title{
cis-Dioxido-molybdenum(VI) complexes of tridentate ONO hydrazone Schiff base: Synthesis, characterization, X-ray crystal structure, DFT calculation and catalytic activity
}

\author{
S. Yousef Ebrahimipour ${ }^{\text {a,* }}$, Hojatollah Khabazadeh ${ }^{a}$, Jesús Castro ${ }^{b}$, Iran Sheikhshoaie ${ }^{a}$, Aurelien Crochet $^{c, d}$, \\ Katharina M. Fromm ${ }^{\mathrm{d}}$ \\ ${ }^{a}$ Department of Chemistry, Faculty of Science, Shahid Bahonar University of Kerman, Kerman, Iran \\ ${ }^{\mathrm{b}}$ Departamento de Química Inorgánica, Universidade de Vigo, Facultade de Química, Edificio de Ciencias Experimentais, 36310 Vigo, Galicia, Spain \\ ${ }^{\mathrm{c}}$ FriMat, University of Fribourg, Chemin du Musée 6, CH-1700 Fribourg, Switzerland \\ ${ }^{\mathrm{d}}$ Department of Chemistry, University of Fribourg, Chemin du Musée 9, CH-1700 Fribourg, Switzerland
}

Two new cis- $\mathrm{MoO}_{2}\left[\mathrm{MoO}_{2}(\mathrm{~L})(\mathrm{EtOH})\right](\mathbf{1}),\left[\mathrm{MoO}_{2}(\mathrm{~L})(\mathrm{Py})\right]$ (2) [L: (3-methoxy-2oxidobenzylidene)benzohydrazidato], complexes have been synthesized and fully characterized on the basis of elemental analysis, FT-IR, molar conductivity, ${ }^{1} \mathrm{H}$ NMR, ${ }^{13} \mathrm{C}$ NMR and electronic spectra. The structure of complexes has been accomplished by single crystal X-ray diffraction. All experimental results confirmed that both complexes have an octahedral geometry around the $\mathrm{Mo}(\mathrm{VI})$ central atom, which is coordinated by the donor atoms of the dianionic hydrazone ligand, two oxido groups and oxygen/nitrogen atoms of solvent molecules. Computational studies were also performed using DFT calculations at B3LYP/DGDZVP level of theory. Furthermore, their catalytic activities were investigated on the electrophilic reaction of indole with aldehydes in molten tetrabutyl ammonium bromide (TBAB) to obtain bis(indolyl)methane derivatives.

\section{Introduction}

During recent years, aryl hydrazone Schiff base ligands, and their transition metal complexes, have attracted more and more attention [1]. They are widely used in different areas, not only because of their facile synthesis, but also for potential biological, catalytic, and industrial applications [2,3]. Many recent reports show that they are good candidates for the development of new drugs as well as their usage in other biochemical processes like enzyme inhibition, or the simulation of antimicrobial, anti-cancer, anti-malarial activities $[4,5]$.

Furthermore molybdenum complexes have a unique place in the development of coordination chemistry [6]. A variety of physicochemical investigation of these compounds provides a clear explanation for their stereochemical and electronic properties. In spite of the important role of molybdenum in biological processes, its high potential as catalyst has made it even more attractive [7].

* Corresponding author at: Department of Chemistry, Faculty of Science, Shahid Bahonar University of Kerman, 76169-14111 Kerman, Iran. Tel./fax: +98 343132 2143.

E-mail addresses: Ebrahimipour@uk.ac.ir, Ebrahimipour@ymail.com (S.Y. Ebrahimipour).
Molybdenum complexes, especially molybdenum(VI) dioxidocomplexes, are widely used as efficient catalysts in different processes such as the oxidation of olefins and sulfides [8].

Moreover, indole rings are featured in a wide variety of biologically active compounds [9]. Some of the ring-substituted bis(indolyl)methanes such as 1,1-bis(3-indolyl)-1-(para-substituted phenyl)methanes are cytotoxic to cancer cells and inhibit tumor growth in vivo. For instance, bis(indolyl)methanes containing $p$ trifluoromethyl, tert-butyl and cyano moieties activate the peroxisome proliferator-activated receptor $\mathrm{c}$ (PPARc), whereas the methoxy and unsubstituted analogs activate the nerve growth factor induced-Ba (Nur77), an orphan nuclear receptor. Both PPARc-active and Nur77-active bis(indolyl)methanes induce both receptor-dependent and -independent growth inhibitory and proapoptotic pathways in cancer cells and tumors including activation of ER stress in both pancreatic and ovarian cancer cell lines [10]. Consequently, numerous methods have been reported for the synthesis of bis(indolyl)methanes. Of these methods, the acid-catalysed electrophilic substitution reaction of indoles with aldehydes is one of the most simple and straightforward approaches for the synthesis of bis(indolyl)methanes [11-13]. However, some of the reported methods have the following drawbacks: for example, use of expensive reagents, longer reaction time and low yields of products. 
In this study, two cis- $\mathrm{MoO}_{2}$ complexes containing tridentate hydrazine Schiff base, (2-hydroxy-3-methoxybenzylidene)benzohydrazide [HL], were synthesized and fully characterized with spectroscopic methods. DFT calculations were also performed at B3LYP/DGDZVP level of theory. Finally the catalytic activity of these complexes was investigated in the synthesis of bis(indolyl) methane derivatives.

\section{Experimental}

\subsection{Materials and instrumentation}

All chemicals and solvents used were of analytical reagent grade and were used as received. Micro analyses for $\mathrm{C}, \mathrm{H}, \mathrm{N}$ were carried out using a Perkin Elmer 2400 CHNS/O elemental analyzer. Melting points were measured on an Electrothermal-9100 apparatus and uncorrected. FT-IR spectra were recorded on a FT-IR 8400Shimadzu as $\mathrm{KBr}$ discs in the range of $400-4000 \mathrm{~cm}^{-1}$. Molar Conductance measurements were made by means of a Metrohm 712 Conductometer in DMSO. ${ }^{1} \mathrm{H}$ NMR and ${ }^{13} \mathrm{C}$ NMR spectra were recorded at $25^{\circ} \mathrm{C}$ on the Bruker AVANCE III 500 and $125 \mathrm{MHz}$ spectrometers respectively. Electronic spectra in ethanolic solutions of the complexes were recorded with a Cary 50 UV-Vis spectrophotometer. X-ray diffraction data for $(\mathbf{1})$ were collected using a Stoe IPDS II diffractometer, equipped with an Oxford cryostat and in case of (2), with a Bruker Smart 6000 diffractometer.

\subsection{Synthesis of (2-hydroxy-3-methoxybenzylidene)benzohydrazide [HL]}

An ethanolic solution $(6 \mathrm{~mL})$ containing $1 \mathrm{mmol}$ of 3-methoxy2-hydroxy benzaldehyde $(0.152 \mathrm{~g})$ was added dropwise to an ethanolic solution of benzohydrazide ( $1 \mathrm{mmol}, 0.136 \mathrm{~g}$ ) with constant stirring. The mixtures were refluxed for $15 \mathrm{~min}$. and the resulting precipitates were filtered off, washed with cold ethanol and dried in desiccator over silica gel.

Yield: 0.224 g, $83 \%$. m.p.: $116{ }^{\circ} \mathrm{C}$. Anal. Calc. for $\mathrm{C}_{15} \mathrm{H}_{14} \mathrm{~N}_{2} \mathrm{O}_{3}$ (270.28 $\mathrm{g} \mathrm{mol}^{-1}$ ): C, 66.66; H, 5.22; N, 10.36. Found: C, 66.18; H, 5.30; N, 10.53\%. FT-IR (KBr), $\mathrm{cm}^{-1}: v(\mathrm{NH}) 3571, v(\mathrm{OH}) 3367, v\left(\mathrm{CH}_{\mathrm{ar}}\right)$ 2839-3062, $v(\mathrm{C}=\mathrm{O}) 1647, v(\mathrm{C}=\mathrm{N}) 1610, v\left(\mathrm{C}=\mathrm{C}_{\text {ring }}\right) 1470, v(\mathrm{~N}-\mathrm{N})$ 1149, $v(\mathrm{C}-\mathrm{O})$ 1296. ${ }^{1} \mathrm{H}$ NMR $\left(500 \mathrm{MHz}\right.$, DMSO- $\left.d_{6}, 25 \mathrm{C}, \mathrm{ppm}\right)$ : $\delta=12.10(\mathrm{~s}, 1 \mathrm{H} ; \mathrm{NH}), 11.03(\mathrm{~s}, 1 \mathrm{H} ; \mathrm{OH}), 8.67(\mathrm{~s}, 1 \mathrm{H} ; \mathrm{CH}=\mathrm{N})$ 6.85-7.96 (m, 8H, rings), $3.82\left(\mathrm{~s}, 3 \mathrm{H}, \mathrm{OCH}_{3}\right) .{ }^{13} \mathrm{C} \mathrm{NMR}(125 \mathrm{MHz}$, DMSO- $\left.d_{6}, 25^{\circ} \mathrm{C}, \mathrm{ppm}\right): 163.7,149.1,148.8,148.1,133.7,132.8$, 129.4, 128.5, 121.7, 119.9, 119.7, 114.7, 56.6. UV-Vis (EtOH) $\lambda_{\max }$ $\mathrm{nm}\left(\log \varepsilon, \mathrm{L} \mathrm{mol}^{-1} \mathrm{~cm}^{-1}\right): 225$ (4.53), 305 (4.60), 343 (4.07).

2.3. Synthesis of ethanol (3-methoxy-2-

oxidobenzylidene)benzohydrazonato dioxidomolybdenum(VI) $\left[\mathrm{MoO}_{2}(\mathrm{~L})(\mathrm{EtOH})\right](\mathbf{1})$

An ethanolic solution $(4 \mathrm{ml})$ of $\mathrm{MoO}_{2}(\mathrm{acac})_{2}(0.1 \mathrm{mmol}, 0.03 \mathrm{~g})$ was added to a solution of $\mathrm{HL}(0.1 \mathrm{mmol}, 0.03 \mathrm{~g})$ in ethanol $(3 \mathrm{ml})$ and the resulting orange mixture was refluxed for $30 \mathrm{~min}$. After cooling, the solution was filtered and left to stand overnight. Orange crystals suitable for crystallography separated after two days and were dried in a vacuum desiccator over silica gel.

Yield: $0.027 \mathrm{~g}, 62 \%$ m.p.: $233^{\circ} \mathrm{C}$. Molar conductance $\left(10^{-3} \mathrm{M}\right.$, DMSO): $27 \mathrm{ohm}^{-1} \mathrm{~cm}^{2} \mathrm{~mol}^{-1}$. Anal. Calc. for $\mathrm{C}_{17} \mathrm{H}_{18} \mathrm{MoN}_{2} \mathrm{O}_{6}$ (442.29 $\left.\mathrm{g} \mathrm{mol}^{-1}\right)$ : C, 46.16; $\mathrm{H}, 4.10$; N, 6.33. Found: C, 46.12; $\mathrm{H}$, $4.41 ; \mathrm{N}, 6.21 \%$. IR $(\mathrm{KBr}) \mathrm{cm}^{-1}: v(\mathrm{OH}) 3298, v\left(\mathrm{CH}_{\mathrm{ar}}\right)$ 2815-2981, $v(\mathrm{C}=\mathrm{N}) 1602, v\left(\mathrm{C}=\mathrm{C}_{\text {ring }}\right) 1450, v(\mathrm{~N}-\mathrm{N}) 1126, v(\mathrm{C}-\mathrm{O}) 1257, v_{\text {sy }}($ cis$\left.\mathrm{MoO}_{2}\right)$ 941, $v_{\text {asy }}\left(\right.$ cis- $\left.-\mathrm{MoO}_{2}\right)$ 910. ${ }^{1} \mathrm{H}$ NMR $(500 \mathrm{MHz}$, DMSO-d $\left.25^{\circ} \mathrm{C}, \mathrm{ppm}\right): \delta=8.93(\mathrm{~s}, 1 \mathrm{H} ; \mathrm{CN}), 7.01-8.01$ (m, $8 \mathrm{H}$; rings), 4.36 $(\mathrm{s}, 1 \mathrm{H}, \mathrm{OH}), 3.80\left(\mathrm{~s}, 3 \mathrm{H} ; \mathrm{OCH}_{3}\right), 3.43\left(\mathrm{~s}, 3 \mathrm{H} ; \mathrm{CH}_{3}\right), 1.07(\mathrm{~s}, 2 \mathrm{H}$,
$\left.\mathrm{CH}_{2}\right) .{ }^{13} \mathrm{C}$ NMR $\left(125 \mathrm{MHz}\right.$, DMSO- $\left.d_{6}, 25 \mathrm{C}, \mathrm{ppm}\right): 168.7,156.0$, $149.1,148.4,132.0,129.9,128.8,127.9,125.3,121.5,120.5$, 117.1, 56.0, 55.8, 18.5. UV-Vis (EtOH) $\lambda_{\max }, \mathrm{nm}(\log \varepsilon$, $\mathrm{L} \mathrm{mol}^{-1} \mathrm{~cm}^{-1}$ ): 222(4.71), 303(4.57), 340(4.25), 429(3.40).

2.4. Synthesis of pyridine ethanol (3-methoxy-2-oxidobenzylidene) benzohydrazonato dioxidomolybdenum(VI) $\left[\mathrm{MoO}_{2}(\mathrm{~L})(\mathrm{py})\right](2)$

$\mathrm{MoO}_{2}(\mathrm{acac})_{2}(0.1 \mathrm{mmol}, 0.03 \mathrm{~g})$ and $\mathrm{HL}(0.1 \mathrm{mmol}, 0.03 \mathrm{~g})$ were added to $6 \mathrm{ml}$ ethanol/pyridine (3:3) solution and the mixture stirred for $\mathrm{ca} 1 \mathrm{~h}$. to give a dark orange solution. After 2 days, suitable single crystals appeared on slow evaporation of solvent. The resulting product was isolated, and dried in vacuum desiccator over silica gel.

Yield: 0.036 g, $67 \%$. m.p.: $246^{\circ} \mathrm{C}$. Molar conductance $\left(10^{-3} \mathrm{M}\right.$, DMSO): $31 \mathrm{ohm}^{-1} \mathrm{~cm}^{2} \mathrm{~mol}^{-1}$. Anal. Calc. for $\mathrm{C}_{20} \mathrm{H}_{17} \mathrm{MoN}_{3} \mathrm{O}_{5} 0.5$ $\left(\mathrm{C}_{5} \mathrm{H}_{5} \mathrm{~N}\right)\left(515.86 \mathrm{~g} \mathrm{~mol}^{-1}\right): \mathrm{C}, 51.27 ; \mathrm{H}, 3.72 ; \mathrm{N}, 10.87$. Found: $\mathrm{C}$, 50.83; H, 3.17; N, 10.46\%. IR ( $\mathrm{KBr}) \mathrm{cm}^{-1}: v\left(\mathrm{CH}_{\mathrm{ar}}\right)$ 2835-3059, $v(\mathrm{C}=\mathrm{N}) 1604, v\left(\mathrm{C}=\mathrm{C}_{\text {ring }}\right) 1446, v(\mathrm{~N}-\mathrm{N}) 1130, v(\mathrm{C}-\mathrm{O}) 1254, v_{\text {sy }}$ (cis$\left.\mathrm{MoO}_{2}\right)$ 928, $v_{\text {asy }}\left(\mathrm{cis}-\mathrm{MoO}_{2}\right)$ 906. ${ }^{1} \mathrm{H}$ NMR $(500 \mathrm{MHz}$, DMSO-d $\left.25^{\circ} \mathrm{C}, \mathrm{ppm}\right): \delta=8.94(\mathrm{~s}, 1 \mathrm{H} ; \mathrm{CN}), 8.57(\mathrm{~s}, 2 \mathrm{H}, 2 \mathrm{CH}), 7.03-8.01(\mathrm{~m}$, $11 \mathrm{H}$; rings), $3.80\left(\mathrm{~s}, 3 \mathrm{H} ; \mathrm{OCH}_{3}\right) .{ }^{13} \mathrm{C}$ NMR $\left(125 \mathrm{MHz}\right.$, DMSO- $d_{6}$, 25 C, ppm): 168.8, 156.1, 149.6, 149.2, 148.5, 136.2, 132.0, 130.0, $128.8,127.9,125.3,123.9,121.5,120.5,117.1$. UV-Vis $(\mathrm{EtOH}) \lambda_{\max }$, $\mathrm{nm}\left(\log \varepsilon, \quad \mathrm{L} \mathrm{mol}^{-1} \mathrm{~cm}^{-1}\right): \quad 223(4.78), \quad 303(4.60), \quad 339(4.30)$, 439(3.45).

2.5. General procedure for the Mo-catalyzed reaction of indole with aldehydes

A mixture of indole $(2 \mathrm{mmol})$, aldehyde $(1 \mathrm{mmol})$ and Mocomplex $(0.1 \mathrm{mmol})$ in tetrabutylammonium bromide $(2 \mathrm{mmol})$ was stirred at $110^{\circ} \mathrm{C}$ for the appropriate time (see Section 3.6). The progress of the reaction was monitored by TLC. When the reaction was completed the reaction mixture was dissolved in ethanol and poured into water. The resulting precipitate was filtered and purified by silica gel column chromatography using chloroform as eluent, to afford the desired compound in pure form.

\subsection{Spectral data of selected compounds}

\subsubsection{Benzyledenebis(indolyl)methane $(A)$}

FT-IR (KBr) $\left(v_{\max }, \mathrm{cm}^{-1}\right): 1492,1599,1616,2960,3054,3411$. ${ }^{1} \mathrm{H}$ NMR (500 MHz, $\left.\mathrm{CDCl}_{3}\right) \delta: 5.94(1 \mathrm{H}, \mathrm{s}, \mathrm{CH}$ aliphatic), 6.68 (d, $J=1.6 \mathrm{~Hz}, 2 \mathrm{H}, 2 \mathrm{CH}), 7.06(\mathrm{t}, J=7.2 \mathrm{~Hz}, 2 \mathrm{H}, \mathrm{Ar}-\mathrm{H}), 7.21-7.46(\mathrm{~m}$, $8 \mathrm{H}, \mathrm{Ar}-\mathrm{H}), 7.89(\mathrm{~s}, \mathrm{br}, 2 \mathrm{H}, 2 \mathrm{NH}) .{ }^{13} \mathrm{C}$ NMR $\left(125 \mathrm{MHz}, \mathrm{CDCl}_{3}\right) \delta$ : $40.7,111.4,119.8,120.3,122.3,123.8,126.3,127.5,127.7,128.4$, $128.6,137.1,144.4$.

\subsubsection{2-Chlorobenzyledenebis(indolyl)methane (C)}

FT-IR $(\mathrm{KBr})\left(v_{\max }, \mathrm{cm}^{-1}\right): 1549,1617,3054,3411 .{ }^{1} \mathrm{H}$ NMR $\left(500 \mathrm{MHz}, \mathrm{CDCl}_{3}\right) \delta: 6.40(\mathrm{~s}, 1 \mathrm{H}, \mathrm{CH}$ aliphatic), $6.65(\mathrm{t}, 2 \mathrm{H}$, $J=0.8 \mathrm{~Hz}), 7.06-7.49(\mathrm{~m}, 12 \mathrm{H}, \mathrm{Ar}-\mathrm{H}), 7.88(\mathrm{~s}, 2 \mathrm{H}, \mathrm{br}, \mathrm{NH}) .{ }^{13} \mathrm{C}$ NMR $\left(125 \mathrm{MHz}, \mathrm{CDCl}_{3}\right) \delta: 37.0,111.5,118.8,119.7,120.3,122.5$, $124.2,127.1,127.4,127.9,129.9,130.8,134.4,137.1,141.8$.

\subsection{Crystal structure determination}

In the case of $\left[\mathrm{MoO}_{2}(\mathrm{~L})(\mathrm{EtOH})\right](\mathbf{1})$, data collection by using Mo $\mathrm{K} \alpha$ radiation $(\lambda=0.71073 \AA$ ) was performed at $200 \mathrm{~K}$ with a Stoe IPDS II diffractometer, equipped with an Oxford cryostat. Absorption correction was partially integrated in the data reduction procedure. The structure was solved and refined using full-matrix least-squares on $F^{2}$ with the sHeLx-97 package [14]. Crystallographic data for (2) were collected at room temperature using a Bruker Smart $6000 \mathrm{CCD}$ detector and $\mathrm{Cu} \mathrm{K} \alpha$ radiation $(\lambda=1.54178 \AA$ ) 
generated by a Incoatec microfocus source equipped with Incoatec Quazar MX optics. The software APEX2 was used for collecting frames of data, indexing reflections, and the determination of lattice parameters, SAINT for integration of intensity of reflections, and SADABS for scaling and empirical absorption correction [15].

The crystallographic treatment of (2) was performed with the oscall program [16], the structure was solved by direct methods and refined by a full-matrix least-squares based on $F^{2}$ [17]. Nonhydrogen atoms were refined with anisotropic displacement parameters. Hydrogen atoms were included in idealized positions and refined with isotropic displacement parameters. The asymmetric unit of (2) contains a molybdenum complex molecule and a half of a solvent pyridine molecule. Three atoms are found in the density map for this one, two carbon atoms and the other one was interpreted as half nitrogen and half carbon, although refined as nitrogen. Details of crystal data and structural refinement are given in Table 1 .

\subsection{Computational}

Full geometry optimization of the complexes and proposed intermediates was carried out using DFT-B3LYP [18] with DGDZVP basis set [19] using the G03 program [20]. Starting geometries for calculation were taken from the X-ray crystal structure of the related complexes. To validate the optimization of the structures, frequency calculations were performed and the results showed no negative (imaginary) frequency.

UV-Vis spectra, electronic transitions, absorbance and oscillator strengths were computed with the time-dependent DFT (TD-DFT) method at the DGDZVP level. Solvent (EtOH) was considered as a uniform dielectric constant 24.55 and Polarized Continuum Model (PCM). GAUSSSUM 3.0 with FWHM $0.3 \mathrm{eV}$ have been used for analyzing the contribution percentage of groups and atoms to the molecular orbitals [21].

To have a better understanding of the feasibility of the title reactions, the relative electronic energies for all of the intermediates arising from the reaction of indole with benzaldehyde in the presence of the complex 1 were calculated at the B3LYP/GGDZVP level of theory (ZPE energies and solvent effects are not included).

\section{Results and discussion}

The reaction of $\mathrm{MoO}_{2}(\mathrm{acac})_{2}$ with tridentate hydrazine Schiff base ligand (HL) in different solvents has been led to formation of cis- $\mathrm{MoO}_{2}$ complexes in good yield. Schiff base ligand (HL) contributes in all prepared complexes in its enolic form that the schematic diagram for synthesis of complexes are shown in Fig. 1. The obtained complexes are stable in room temperature

Table 1

Crystal data and structure refinement for $\mathbf{1}$ and $\mathbf{2}$.

\begin{tabular}{|c|c|c|}
\hline Empirical formula & $\mathrm{C}_{17} \mathrm{H}_{18} \mathrm{MoN}_{2} \mathrm{O}_{6}$ & $\mathrm{C}_{22} \mathrm{H}_{19.5} \mathrm{MoN}_{4} \mathrm{O}_{5}$ \\
\hline Moiety formula & $\mathrm{C}_{17} \mathrm{H}_{18} \mathrm{MoN}_{2} \mathrm{O}_{6}$ & $\mathrm{C}_{20} \mathrm{H}_{17} \mathrm{MoN}_{3} \mathrm{O}_{5} 0.5\left(\mathrm{C}_{5} \mathrm{H}_{5} \mathrm{~N}\right)$ \\
\hline Formula weight & 442.29 & 515.86 \\
\hline Temperature (K) & $200(2)$ & $296(2)$ \\
\hline Wavelength $(\AA)$ & 0.71073 & 1.54178 \\
\hline Crystal system & triclinic & monoclinic \\
\hline Space group & $P \overline{1}$ & $C 2 / c$ \\
\hline \multicolumn{3}{|l|}{ Unit cell dimensions } \\
\hline$a(\AA)$ & $7.4364(4)$ & $25.0954(5)$ \\
\hline$b(\AA)$ & $10.7370(6)$ & $11.3916(2)$ \\
\hline$c(\AA)$ & $11.9559(7)$ & $15.8798(3)$ \\
\hline$\alpha\left({ }^{\circ}\right)$ & $111.896(4)$ & 90 \\
\hline$\beta\left({ }^{\circ}\right)$ & $96.601(5)$ & $111.5501(5)$ \\
\hline$\gamma\left({ }^{\circ}\right)$ & $95.344(5)$ & 90 \\
\hline$V\left(\AA^{3}\right)$ & $870.25(8)$ & $4222.33(14)$ \\
\hline$Z$ & 2 & 8 \\
\hline Density (calculated) $\left(\mathrm{Mg} / \mathrm{m}^{3}\right)$ & 1.688 & 1.623 \\
\hline $\begin{array}{l}\text { Absorption coefficient } \\
\qquad\left(\mathrm{mm}^{-1}\right)\end{array}$ & 0.791 & 5.457 \\
\hline$F(000)$ & 448 & 2092 \\
\hline Crystal size (mm) & $0.14 \times 0.10 \times 0.06$ & $0.24 \times 0.11 \times 0.11$ \\
\hline $\begin{array}{l}\text { Theta range for data } \\
\text { collection }\left(^{\circ}\right)\end{array}$ & $1.86-25.73$ & $3.79-68.07$ \\
\hline \multirow[t]{3}{*}{ Index ranges } & $-9 \leqslant h \leqslant 9$ & $-29 \leqslant h \leqslant 30$ \\
\hline & $-13 \leqslant k \leqslant 12$ & $-12 \leqslant k \leqslant 13$ \\
\hline & $-14 \leqslant l \leqslant 14$ & $-18 \leqslant l \leqslant 18$ \\
\hline Reflections collected & 17805 & 19144 \\
\hline Independent reflections $\left(R_{\mathrm{int}}\right)$ & $3279(0.0362)$ & $3707(0.0293)$ \\
\hline Reflections observed $(>2 \sigma)$ & 3007 & 3602 \\
\hline Data Completeness & 0.987 & 0.959 \\
\hline Absorption correction & integration & $\begin{array}{l}\text { semi-empirical from } \\
\text { equivalents }\end{array}$ \\
\hline $\begin{array}{l}\text { Maximum and minimum } \\
\text { transmission }\end{array}$ & 0.8552 and 0.6411 & 0.7530 and 0.5394 \\
\hline Refinement method & $\begin{array}{l}\text { full-matrix least- } \\
\text { squares on } F^{2}\end{array}$ & $\begin{array}{l}\text { full-matrix least-squares } \\
\text { on } F^{2}\end{array}$ \\
\hline Data/restraints/parameters & $3279 / 1 / 240$ & $3707 / 0 / 285$ \\
\hline Goodness-of-fit (GOF) on $F^{2}$ & 1.037 & 1.077 \\
\hline Final $R$ indices $[I>2 \sigma(I)]$ & $\begin{array}{l}R_{1}=0.0212 \\
w R_{2}=0.0536\end{array}$ & $\begin{array}{l}R_{1}=0.0233 \\
w R_{2}=0.0640\end{array}$ \\
\hline$R$ indices (all data) & $\begin{array}{l}R_{1}=0.0245 \\
w R_{2}=0.0570\end{array}$ & $\begin{array}{l}R_{1}=0.0238 \\
w R_{2}=0.0645\end{array}$ \\
\hline $\begin{array}{l}\text { Largest difference in peak } \\
\text { and hole }\left(\mathrm{e} \AA^{-3}\right)\end{array}$ & 0.380 and -0.558 & 0.288 and -0.714 \\
\hline
\end{tabular}




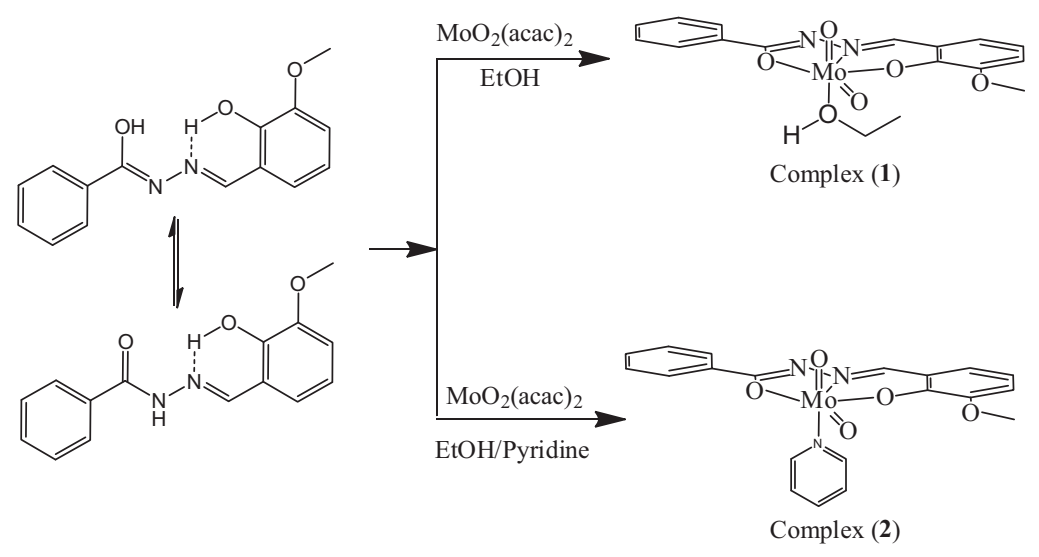

Fig. 1. Schematic diagram for complexation processes.

and soluble in DMSO, DMF, ethanol and less soluble in other common solvents like dichloromethane, acetonitrile and insoluble in benzene, $n$-hexane and $\mathrm{CCl}_{4}$. the low molar solution conductance of the complexes in DMSO, indicating the complexes have non electrolyte behavior.

\subsection{Spectral characterizations}

\subsubsection{FT-IR}

Assignments of selected prominent IR bands in the 400$4000 \mathrm{~cm}^{-1}$ region for $\mathrm{HL}$ and its $\mathrm{Mo}(\mathrm{VI})$ complexes are listed in the Section 2. In the FT-IR spectrum of the ligand, the band with high intensity at $3571 \mathrm{~cm}^{-1}$ corresponds to the $\mathrm{NH}$ vibration. The stretching vibrations of carbonyl group $(C=O)$ appear at $1647 \mathrm{~cm}^{-1}$ [22]. The absence of these bands in the IR spectra of the $\mathrm{Mo}(\mathrm{VI})$ complexes indicates that the free HL exists in its keto form while in its complexes, it contributes in its enolic form. The characteristic strong band of the $\mathrm{CN}$ moiety in the ligand is assigned to $1610 \mathrm{~cm}^{-1}$ while in the complexes, this band shifts to lower wave numbers $\left(1602 \mathrm{~cm}^{-1}(\mathbf{1}), 1604 \mathrm{~cm}^{-1}(\mathbf{2})\right)$, supporting the coordination of the azomethine nitrogen to the central atom in complexes [23]. After complexation, the red shift of the CO vibration toward lower wave number indicates that coordination also takes place through deprotonated phenolic and aliphatic oxygen atoms [24]. The symmetric vibrations of cis- $\mathrm{MoO}_{2}$ are disclosed at 941 and $928 \mathrm{~cm}^{-1}$ for (1) and (2) respectively [25]. Furthermore the strong bands at $910 \mathrm{~cm}^{-1}$ for (1) and $906 \mathrm{~cm}^{-1}$ for (2) are assignable to the asymmetric vibration of the cis- $\mathrm{MoO}_{2}$ group [26,27].

\subsubsection{NMR spectral studies}

The ${ }^{1} \mathrm{H}$ NMR and ${ }^{13} \mathrm{C}$ NMR data for the compounds in DMSO are listed in the Section 2 and presented in Figs. S1-S6. In the spectrum of HL singlet signal at $12.10 \mathrm{ppm}$ and $11.03 \mathrm{ppm}$ are attributed to $\mathrm{OH}$ and $\mathrm{NH}$ respectively [28]. Disappearance of these signals in these complexes confirms the coordination occurs through the deprotonated hydroxyl groups. The methine proton is revealed at $8.67 \mathrm{ppm}$ in $\mathrm{HL}$, which upon coordination, in the complexes, shows significant up-field shifts proving the coordination of the azomethine nitrogen to the metal center [23]. The singlet signal at about $3.8 \mathrm{ppm}$ in the compounds corresponds to protons of the methoxy group. The protons of the rings are found between 6.85 and $8.01 \mathrm{ppm}$ although in compound 2, the $\mathrm{C}^{110} \mathrm{H}$ and $\mathrm{C}^{6} \mathrm{H}$ protons of pyridine were disclosed at $8.57 \mathrm{ppm}$ as a singlet signal. In case of compound (1), Hydroxyl protons of ethanol are disclosed at $4.36 \mathrm{ppm}$ and the other signals at 3.43 and $1.07 \mathrm{ppm}$ correspond to $\mathrm{CH}_{3}$ and $\mathrm{CH}_{2}$ groups of coordinated ethanol respectively.
In the ${ }^{13} \mathrm{C}$ NMR spectrum of $\mathrm{HL}$, the chemical shift positions of carbonyl, phenolic and methine carbon atoms are observed at 163.7, 148.8 and $148.1 \mathrm{ppm}$, respectively [22]. Upon coordination, these signals shift to lower field showing that the donor atoms (ONO) of $[\mathrm{HL}]$ are now connected to the molybdenum central atom.

\subsection{X-ray structures description}

Compounds $\left[\mathrm{MoO}_{2}(\mathrm{~L})(\mathrm{EtOH})\right](\mathbf{1})$ and $\left[\mathrm{MoO}_{2}(\mathrm{~L})(\mathrm{py})\right](\mathbf{2})$ consist of a molybdenum( $\mathrm{VI})$ atom coordinated by an dianionic tridentate $\mathrm{N}$-[(3-methoxy)2-(oxido)benzylidene] benzenecarbohydrazonato ligand, binding via two O-atoms and one $\mathrm{N}$-atom. A sixth ligand
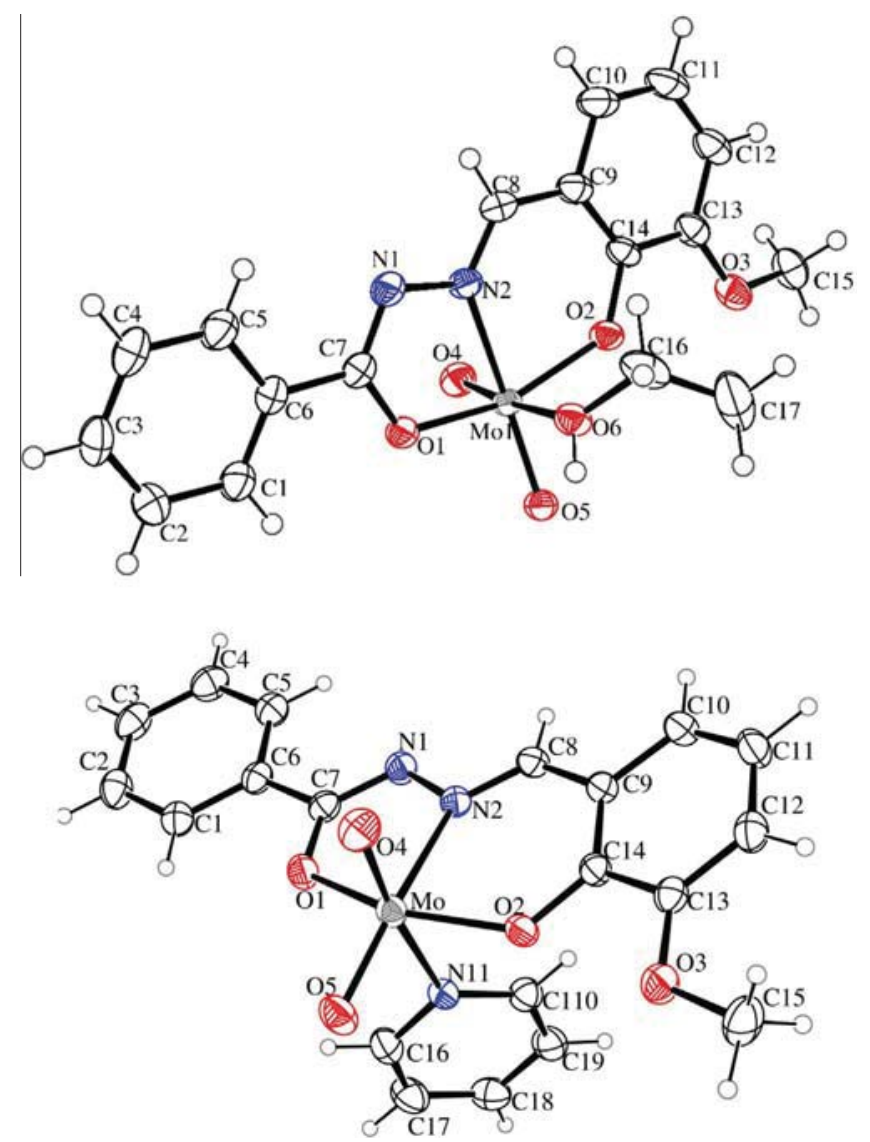

Fig. 2. ORTEP diagram of $\left[\mathrm{MoO}_{2}(\mathrm{~L})(\mathrm{EtOH})\right]$ (1). (50\% probability level) and of $\left[\mathrm{MoO}_{2}(\mathrm{~L})(\mathrm{py})\right](\mathbf{2})$ (30\% probability level). 
completes the coordination sphere, i.e., an EtOH (1) or a pyridine (2) ligand. It is worth noting that in all cases, these ligands are weakly bonded (see below).

The calculated bond valence by PLATON (version 271113) [29] for Mo atom is 6.12 for (1) and 6.07 for (2) and confirm the oxidation state +6 for molybdenum atom.

An ORTEP view of the asymmetric unit of the complexes (1) and (2) can be found in Fig. 2. The coordination geometry around the molybdenum(VI) atom shows a distorted octahedral environment with an $\mathrm{NO}_{5}$ [for (1)] or $\mathrm{N}_{2} \mathrm{O}_{4}$ [for (2)] chromophore. Bond distances and angles are set out in Table 2 .

The aroylhydrazone ligand occupies three positions in the meridional plane of the octahedron. One oxido group (05) is located trans to the imine nitrogen in the same plane. The other oxido group (04) occupies one of the axial positions, the second being taken by the coordinated EtOH ligand (1) or the pyridine ligand (2). The two terminal oxido groups $\mathrm{O}(4)$ and $\mathrm{O}(5)$ are hence cis to each other and exhibit typical Mo-O double bond distances 1.686(2) and 1.715(1) A, for (1); and 1.697(1) and 1.697(2) $\AA$ for (2) [30,31]. Metal ligand bond lengths are, for neutral ligands, EtOH in (1) and pyridine in (2) rather long. For (1), the Mo-O bond distance resulted to be $2.358(2) \AA$, quasi the same value to that found $[2.360(5) \AA ̊]$ in a similar complex of formula $\left[\mathrm{MoO}_{2} \mathrm{~L}\left(\mathrm{C}_{2} \mathrm{H}_{5} \mathrm{OH}\right)\right]$ ( $\mathrm{L}=\mathrm{N}$-[1-(2-hydroxynaphthyl)ethylidene]-2-hydroxy benzohydrazide). For this compound this interaction between the EtOH molecule and the molybdenum atom was demonstrated to be a formal bond [32]. In the case of (2), the pyridine donor nitrogen atom - $[\mathrm{N}(1)]$ is situated at $2.448(2) \AA$. This value is longer than the sum of covalent radii (2.25 $\AA$ ) [33] but is was found as a typical bond distance for pyridine coordinated to $\mathrm{MoO}_{2}$ centers [30] In fact a search in the CSD database [34] (version 5.35, Nov. 2013 updated) of $\mathrm{MoO}_{2}$ complexes with environment $\mathrm{MoO}_{4} \mathrm{~N}_{2}$, where one of the i) nitrogen atoms comes from a pyridine ring (excluding 2 -substitued pyridine such chelating ligands derived of 2-amine-pyridine or $2,2^{\prime}$-bipyride) gives 16 compounds and the mean values is $2.461 \AA$, longer than that found in (2). The dihedral angle between the complex equatorial plane and that of the coordinated pyridine ring is $88.58(6)^{\circ}$, hence almost perpendicular, and allowing a $\pi, \pi$ stacking interaction (vide infra). The trans angles between the donor atom of the monodentated ligand (EtOH or py) and the oxo atom $\mathrm{O}(5)$ are, respectively, $172.38(6)^{\circ}$ and $169.64(7)^{\circ}$, indicating considerable distortion of the coordination octahedron around
Table 3

Hydrogen bonds parameters for (1) and (2) ( $\AA$ and ${ }^{\circ}$ ).

\begin{tabular}{lllll}
\hline $\mathrm{D}-\mathrm{H} \ldots \mathrm{A}$ & $d(\mathrm{D}-\mathrm{H})$ & $d(\mathrm{H} \ldots \mathrm{A})$ & $d(\mathrm{D} \ldots \mathrm{A})$ & $\angle(\mathrm{DHA})$ \\
\hline $\mathrm{O}(6)-\mathrm{H}(6) \ldots \mathrm{O}\left(5^{\mathrm{i}}\right)$ & $0.800(17)$ & $1.993(18)$ & $2.775(2)$ & $166(3)$ \\
$\mathrm{C}(8)-\mathrm{H}(8) \ldots \mathrm{O}\left(4^{\mathrm{ii}}\right)$ & 0.95 & 2.50 & $3.158(3)$ & 126 \\
$\mathrm{C}(8)-\mathrm{H}(8) \ldots \mathrm{O}\left(4^{\mathrm{a}}\right)$ & 0.95 & 2.74 & $3.592(2)$ & 152.4 \\
$\mathrm{C}(12)-\mathrm{H}(12) \ldots \mathrm{O}\left(4^{\mathrm{b}}\right)$ & 0.95 & 2.67 & $3.468(3)$ & 144.6 \\
\hline
\end{tabular}

Symmetry transformations used to generate equivalent atoms: $\mathrm{i}-x,-y, 1-z$, $\mathrm{ii}=-x,-y, 2-z, a=0.5-x, 0.5+y, 0.5-z ; b=0.5-x, 1.5-y,-z$.

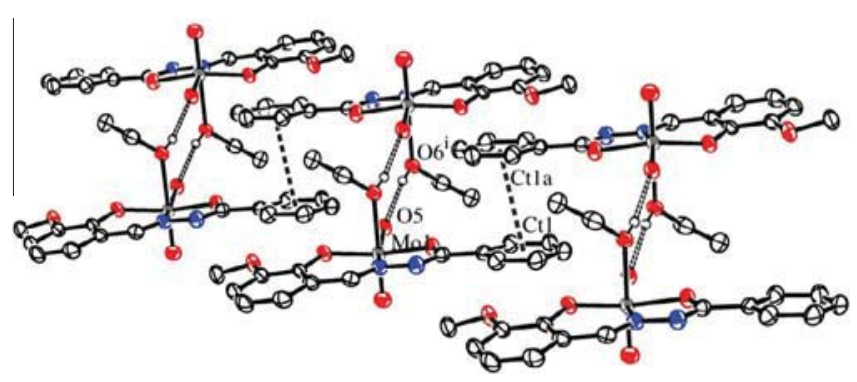

Fig. 3. H-bonds and $\pi, \pi$-stacking interaction between dimeric units ( $a=-x,-1-y$, $1-z)$ in $(\mathbf{1})$.

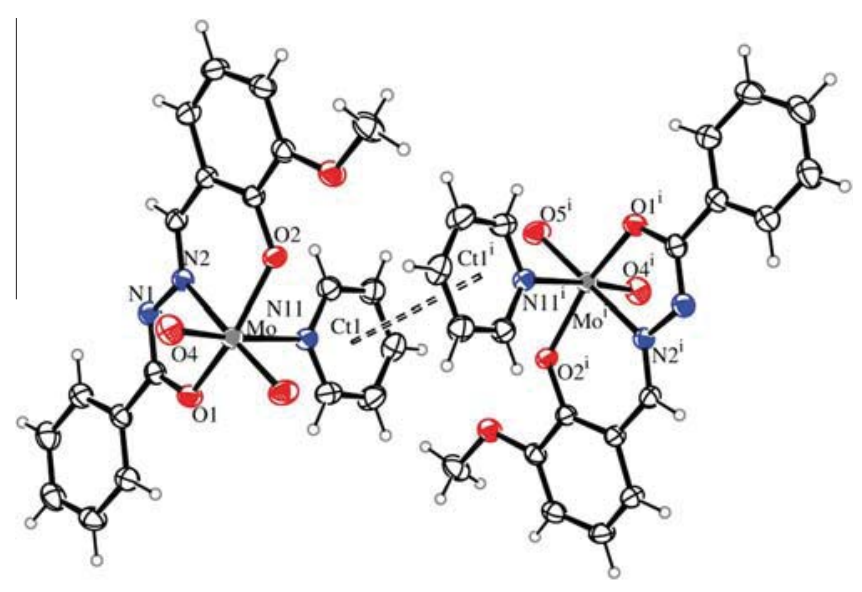

Fig. 4. $\pi-\pi$-stacking interaction $(i=-x, 2-y,-z)$ in (2).

Table 2

Selected bond lengths $(\AA)$ and angles $\left(^{\circ}\right)$ for $(\mathbf{1})$ and $(\mathbf{2})$.

\begin{tabular}{|c|c|c|c|c|}
\hline & \multicolumn{2}{|c|}{$\left[\mathrm{MoO}_{2}(\mathrm{~L})(\mathrm{EtOH})\right](\mathbf{1})$} & \multicolumn{2}{|c|}{$\left[\mathrm{MoO}_{2}(\mathrm{~L})(\mathrm{Py})\right](\mathbf{2})$} \\
\hline & Experimental & Calculated & Experimental & Calculated \\
\hline Mo-O(4) & $1.6855(15)$ & 1.695 & $1.6975(16)$ & 1.701 \\
\hline Mo-O(5) & $1.7153(14)$ & 1.729 & $1.6974(14)$ & 1.710 \\
\hline Mo-O(1) & $1.9930(14)$ & 2.017 & $2.0120(14)$ & 2.015 \\
\hline Mo-O(2) & $1.9234(14)$ & 1.937 & $1.9217(14)$ & 1.931 \\
\hline Mo-N(2) & $2.2215(17)$ & 2.284 & $2.2507(16)$ & 2.292 \\
\hline Mo-O(6)/N(11) & $2.3580(15)$ & 2.443 & $2.4475(18)$ & 2.546 \\
\hline $\mathrm{O}(4)-\mathrm{Mo}-\mathrm{O}(5)$ & $105.82(7)$ & 106.51 & $106.64(8)$ & 106.75 \\
\hline $\mathrm{O}(4)-\mathrm{Mo}-\mathrm{O}(1)$ & $97.86(7)$ & 97.81 & $97.65(7)$ & 98.57 \\
\hline $\mathrm{O}(4)-\mathrm{Mo}-\mathrm{O}(2)$ & $98.72(7)$ & 100.07 & $99.39(7)$ & 99.55 \\
\hline $\mathrm{O}(5)-\mathrm{Mo}-\mathrm{O}(2)$ & $104.54(6)$ & 103.45 & $103.68(7)$ & 104.31 \\
\hline $\mathrm{O}(5)-\mathrm{Mo}-\mathrm{O}(1)$ & $94.94(6)$ & 95.71 & $97.30(7)$ & 96.73 \\
\hline $\mathrm{O}(1)-\mathrm{Mo}-\mathrm{O}(2)$ & $149.80(6)$ & 147.85 & $147.77(6)$ & 146.03 \\
\hline $\mathrm{O}(4)-\mathrm{Mo}-\mathrm{N}(2)$ & $95.94(7)$ & 96.88 & $91.56(7)$ & 91.84 \\
\hline $\mathrm{O}(5)-\mathrm{Mo}-\mathrm{N}(2)$ & $156.05(7)$ & 155.06 & $160.00(7)$ & 159.21 \\
\hline $\mathrm{O}(2)-\mathrm{Mo}-\mathrm{N}(2)$ & $81.43(6)$ & 79.81 & $80.84(6)$ & 79.99 \\
\hline $\mathrm{O}(1)-\mathrm{Mo}-\mathrm{N}(2)$ & $71.88(6)$ & 70.55 & $71.53(5)$ & 71.28 \\
\hline $\mathrm{O}(4)-\mathrm{Mo}-\mathrm{O}(6) / \mathrm{N}(11)$ & $172.38(6)$ & 173.43 & $169.62(7)$ & 170.04 \\
\hline $\mathrm{O}(5)-\mathrm{Mo}-\mathrm{O}(6) / \mathrm{N}(11)$ & $81.58(6)$ & 80.68 & $83.52(7)$ & 81.99 \\
\hline $\mathrm{O}(2)-\mathrm{Mo}-\mathrm{O}(6) / \mathrm{N}(11)$ & $80.87(6)$ & 79.40 & $79.78(6)$ & 79.19 \\
\hline $\mathrm{O}(1)-\mathrm{Mo}-\mathrm{O}(6) / \mathrm{N}(11)$ & $79.41(6)$ & 77.81 & $78.59(6)$ & 77.84 \\
\hline $\mathrm{N}(2)-\mathrm{Mo}-\mathrm{O}(6) / \mathrm{N}(11)$ & $76.46(6)$ & 76.66 & $78.08(6)$ & 79.19 \\
\hline
\end{tabular}



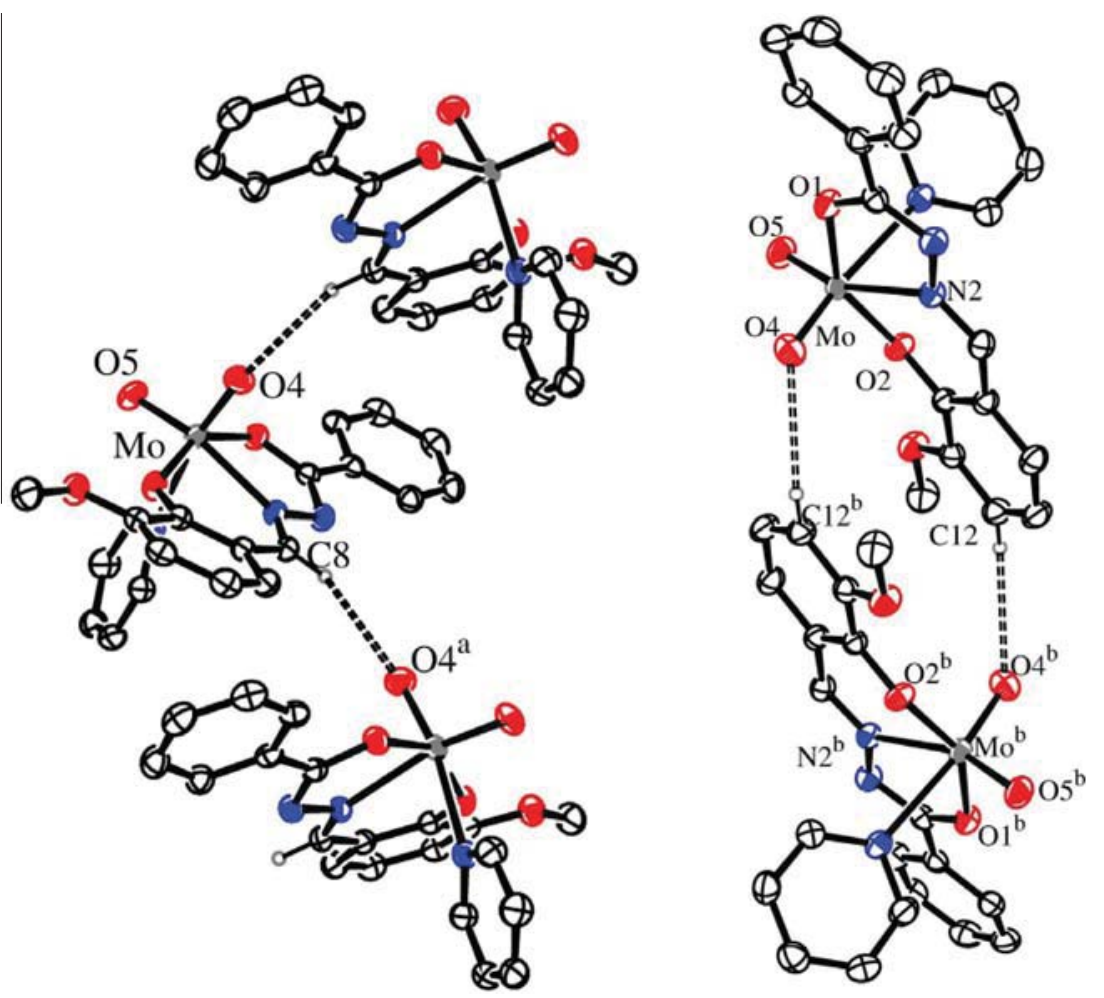

Fig. 5. Left, chain growth due $\mathrm{C}-\mathrm{H} \cdots \mathrm{O}$ interactions. Right, the dimeric units generated by $\mathrm{C}-\mathrm{H} \cdots \mathrm{O}$ interactions for (2).

Table 4

$\mathrm{C}-\mathrm{H} \cdots \pi$ interactions parameters for $(\mathbf{2})\left(\AA \AA\right.$ and $\left.{ }^{\circ}\right)$.

\begin{tabular}{lllll}
\hline $\mathrm{D}-\mathrm{H} . . \mathrm{Cg}$ & $\gamma\left({ }^{\circ}\right)$ & $d(\mathrm{H} . \ldots \mathrm{Cg})(\AA)$ & $d(\mathrm{D}-\mathrm{Ct})(\AA)$ & $\angle(\mathrm{XHCg})\left(^{\circ}\right)$ \\
\hline $\mathrm{C}(11)-\mathrm{H}(11) \ldots \mathrm{Ct}^{\mathrm{a}}$ & 23.40 & 2.95 & $3.705(3)$ & 139.5 \\
$\mathrm{C}(5)-\mathrm{H}(5) \ldots \mathrm{Ct} 4^{\mathrm{c}}$ & 17.39 & 2.94 & $3.651(2)$ & 134.4 \\
\hline
\end{tabular}

Symmetry transformations used to generate equivalent atoms: $a=0.5-x, 0.5+y$, $0.5-z ; c=x, 2-y, 0.5+z$.

the $\mathrm{Mo}(\mathrm{VI})$ center. Such distortion was found in similar pyridine or ethanol $\mathrm{MoO}_{2}$ complexes [28,33]. Chelate angles of $81.43(6)^{\circ}$ or $80.84(6)^{\circ}$ (six-membered ring) and $71.88(6)$ or $71.52(5)^{\circ}$ (fivemembered ring) are also an important source of distortion around metal atom. The five- and six-membered chelate rings form dihedral angles of $6.49(8)^{\circ}$ and $6.43(7)^{\circ}$, respectively, for (1) and of $12.55(8)^{\circ}$ and $7.91(9)^{\circ}$ for $(2)$, respectively. The five membered metallacycle ring is thus rather planar, but the six-membered metallacycle ring is clearly distorted, between envelope or screwboat distortion with distortion parameters of $Q=0.2657(15) \AA$, $\theta=58.6(4)^{\circ}$ and $\varphi=20.9(5)^{\circ}$ for (1) or $Q=0.3756(14) \AA$, $\theta=119.7(3)^{\circ}$ and $\varphi=198.7(3)^{\circ}$ for $(2)$.

The supramolecular arrangement of (1) and (2) are driven by some classical and non-classical hydrogen bonds. Parameters of those interactions are shown in Table 3 One of the classical hydrogen bonds in (1) produces dimeric units as is displayed in Fig. S7, and they are connected with their neighbours by further

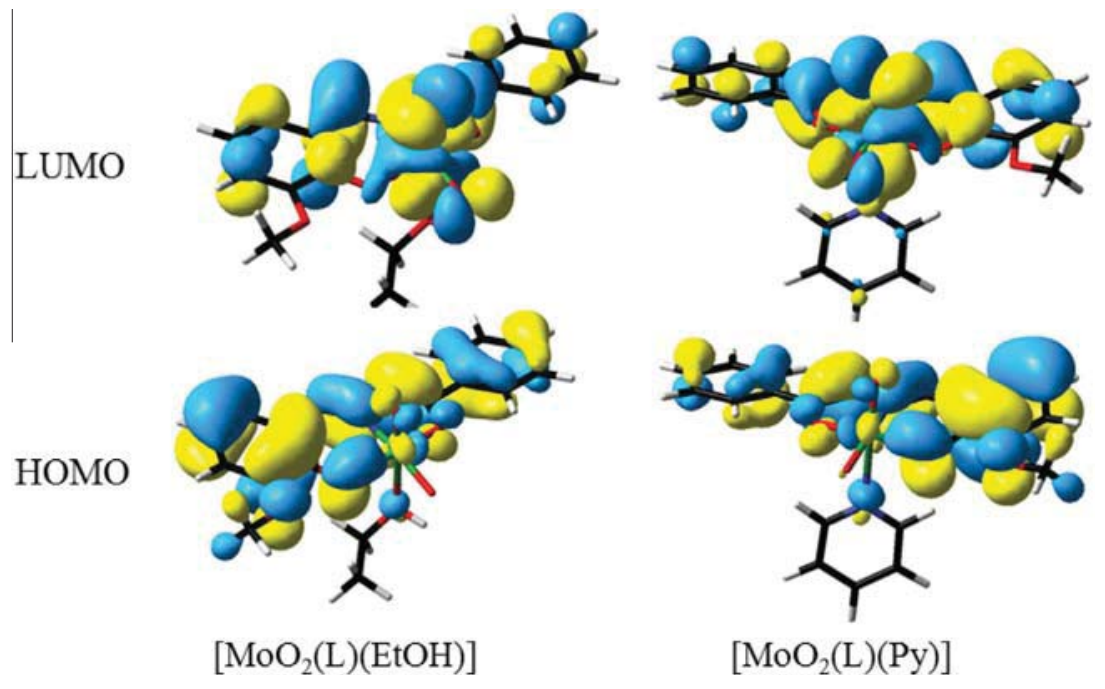

Fig. 6. Frontier molecular orbital (FMO) plots of (1) and (2) complexes. 
interactions. Another interactions in (1) is the non-classical contact between a $\mathrm{C}-\mathrm{H}$ moiety and the oxo group of a neighbour entity, generating the arrangement along the $c$ axis as shown in Fig. S8. A $\pi, \pi$-stacking interaction, shown in Fig. 3., marks the arrangement along the $b$ axis, (symm. op. $=-x,-1-y, 1-z$ ), with a distance between the centroids of 3.612(1) $\AA$ and a slippage parameter of 1.001 A. Fig. S9 shows the unit cell for (1).

In the case of compound (2), the crystal structure contains the metal complex and also one half solvent pyridine molecule, not shown in Fig. 2. This free pyridine molecule is situated on a special position. Its centroid, with positional parameters $0.0,0.3895(2)$, 0.25 , belongs to a wall of the unit cell, and there are no important interactions with the complex molecule [35], but it is occupying free channels in the cell. In the Supplementary material can be found figures showing the unit cell (Figs. S10 and S11) and, for comparison, the unit cell without the free pyridine molecule. The channels are, as can be seen in such figure, free to receive any molecule of appropriate size.

The supramolecular arrangement of $(\mathbf{2})$ is driven by some interactions, e.g., a $\pi-\pi$-stacking interaction between two coordinated pyridine molecules (symm. op. $=-x, 2-y,-z$ ), with centroid distances of 3.661(1) $\AA$ and a slippage parameter of $1.409 \AA$. Dimeric units are generated by these interaction as is shown in Fig. 4 .

Some hydrogen bonds are also found those e.g. between the atoms labeled as $\mathrm{C}(12)$ and $\mathrm{O}(2)$, resulting in dimeric units, and those between $\mathrm{C}(8)$ and $\mathrm{O}(2)$ forming a chain parallel to $b$ axis. Fig. 5 shows both $\mathrm{C}-\mathrm{H} \cdots \mathrm{O}$ interactions. There are also some $\mathrm{C}-$ $\mathrm{H} \cdots \pi$ interactions (Fig. S12). Table 4 set out the parameters of these hydrogen bond interactions. Another $\mathrm{C}-\mathrm{H} \cdots \pi$ interaction takes place between $\mathrm{C}(5)-\mathrm{H}(5) \cdots \mathrm{Ct} 4^{\mathrm{c}}$, (Symm. op. $\left.=x, 2-y, 0.5+z\right)$. This interaction generates an arrangement along the $c$ axis (Fig. S13).

\subsection{Geometry optimization}

Geometrical calculated parameters of (1) and (2) are gathered in Table 2. Starting geometries for calculation were taken from the X-ray crystal structure of the related complexes. As can be seen in Table 2, there is a good agreement between structural parameters from DFT calculation and experimental results. A little difference between theoretical and experimental values may originate from the fact that the experimental data was obtained in the solid state, while the calculated values describe single molecules in the gaseous state without considering lattice interactions [36].

\subsection{Analysis of frontier molecular orbitals}

Frontier Molecular Orbitals (FMO) have an effective role for providing an insight into the chemical reactivities and some of the physical properties of the molecule [22]. Fig. 6 shows the molecular orbital energies with isodensity surface plots of the highest occupied molecular orbital (HOMO) and the lowest unoccupied molecular orbital (LUMO) of the Mo(VI) complexes of this study.

Details of the frontier molecular orbitals in (1) and (2) are shown in Table S1. The HOMO acts as electron donor while the electron accepting ability of a compound is correlated to the LUMO. The molecular stability of the compound can be correlated to its HOMO-LUMO energy gap, more stable structures have higher energy gap. The calculated energy gap for compounds $\mathbf{1}$ and $\mathbf{2}$ are found to be 3.27 and 3.22 respectively, therefore, $\mathbf{1}$ is likely to have higher chemical activity in comparison 2 The HOMO orbitals in both complexes are mainly localized on non-metal atoms. For both complexes the value of contribution of deprotonated Schiff base in HOMO/HOMO-2 is equal to $96-100 \%$ and its role is reduced to $17-38 \%$ for LUMO/LUMO-2. In The lowest unoccupied molecular orbital, the molybdenum center has $63 \%$ electron population for both title complexes. Based on these data, the first transition state from HOMO to LUMO in both complexes can be predicted as an admixture of ILCT and LMCT.

\subsection{Electronic spectra}

The electronic spectra of HL and the title molybdenum(VI) complexes were recorded in EtOH solutions. In the UV-Vis spectra of

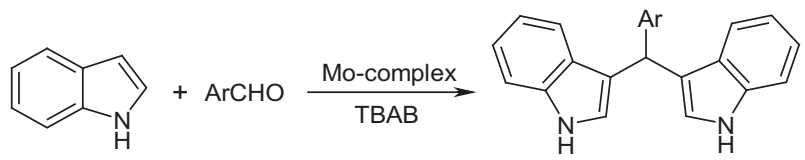

Fig. 7. Synthesis of bis(indolyl) methanes using cis- $\mathrm{MoO}_{2}$ complexes.

Table 5

Calculated and observed $\lambda_{\max }$ values for the principal singlet electronic transitions of (1).

\begin{tabular}{|c|c|c|c|c|c|c|}
\hline Composition & Weight (\%) & $E(\mathrm{eV})$ & Oscillatory strength $(f)$ & $\lambda_{\max }$ (Calc.) & $\lambda_{\max }(\operatorname{Exp})$ & Assignment \\
\hline HOMO $\rightarrow$ LUMO & 69 & 2.4940 & 0.0252 & 422.5605 & 429 & LMCT, ILCT \\
\hline HOMO- $1 \rightarrow$ LUMO & 66 & 2.9032 & 0.0703 & 341.648 & 340 & LMCT, ILCT \\
\hline $\mathrm{HOMO} \rightarrow \mathrm{LUMO}+3$ & 15 & & & & & \\
\hline $\mathrm{HOMO} \rightarrow \mathrm{LUMO}+2$ & 56 & 3.3332 & 0.0455 & 297.576 & 303 & LMCT, ILCT \\
\hline $\mathrm{HOMO} \rightarrow \mathrm{LUMO}+3$ & 34 & & & & & \\
\hline $\mathrm{HOMO} \rightarrow \mathrm{LUMO}+4$ & 58 & 3.5065 & 0.1253 & 282.864 & & ILCT \\
\hline $\mathrm{HOMO}-2 \rightarrow \mathrm{LUMO}+4$ & 46 & 3.7807 & 0.0907 & 229.558 & 222 & ILCT \\
\hline $\mathrm{HOMO}-3 \rightarrow \mathrm{LUMO}+4$ & 19 & & & & & \\
\hline
\end{tabular}

Table 6

Calculated and observed $\lambda_{\max }$ values for the principal singlet electronic transitions of (2).

\begin{tabular}{|c|c|c|c|c|c|c|}
\hline Composition & Weight (\%) & $E(\mathrm{eV})$ & Oscillatory strength $(f)$ & $\lambda_{\max }$ (Calc.) & $\lambda_{\max }(\operatorname{Exp})$ & Assignment \\
\hline HOMO $\rightarrow$ LUMO & 69 & 2.4897 & 0.0185 & 448.191 & 439 & LMCT, ILCT \\
\hline HOMO $\rightarrow$ LUMO+1 & 51 & 2.8786 & 0.0174 & 387.648 & & LMCT, ILCT \\
\hline HOMO-1 $\rightarrow$ LUMO & 46 & & & & & \\
\hline HOMO- $1 \rightarrow$ LUMO & 49 & 2.9297 & 0.0551 & 360.88 & 339 & LMCT, ILCT \\
\hline HOMO $\rightarrow$ LUMO+2 & 15 & & & & & \\
\hline $\mathrm{HOMO} \rightarrow \mathrm{LUMO}+2$ & 51 & 3.3526 & 0.0336 & 332.829 & & LMCT, ILCT \\
\hline $\mathrm{HOMO} \rightarrow \mathrm{LUMO}+3$ & 41 & & & & & \\
\hline HOMO-1 $\rightarrow$ LUMO+3 & 52 & 3.4934 & 0.0985 & 319.419 & 303 & LMCT, ILCT \\
\hline HOMO-1 $\rightarrow$ LUMO+5 & 51 & 3.8430 & 0.2424 & 232.2864 & 223 & ILCT \\
\hline
\end{tabular}


HL, the band at $225 \mathrm{~nm}$ is correlated to $\pi \rightarrow \pi^{*}$ transitions of the aromatic rings. Two bands at 305 and $343 \mathrm{~nm}$ can be assigned to $\pi \rightarrow \pi^{*}$ and $n \rightarrow \pi^{*}$ of the azomethine moiety and the hydrazone ligand [36]. For both complexes, intra-ligand transitions show a shift in comparison with uncomplexed ONO ligand, indicating the enolization followed by deprotonation of the ligand. In all title $\mathrm{Mo}(\mathrm{VI})$ complexes, the bands appearing at about $430 \mathrm{~nm}$ are due to ligand to metal charge transfer (LMCT) $(\mathrm{O}(p) \rightarrow \mathrm{Mo}(d))$ transitions.

For more investigation, the observed and computed electronic transitions based on TD-DFT calculation for (1) and (2) are listed in Tables 5 and 6 respectively. As shown in these tables, the computed values of $\lambda_{\max }$ are in good agreement with the experimental ones. The transitions between $303-429 \mathrm{~nm}$ for 1 and $303-439 \mathrm{~nm}$ for $\mathbf{2}$ can be assigned to an admixture of LMCT and ILCT charge transfer. In case of $\mathbf{1}$ these bands mainly arise from HOMO $\rightarrow$ LUMO $\left(\lambda_{\max }=422.6 \mathrm{~nm}\right)$, HOMO $-1 \rightarrow$ LUMO $\left(\lambda_{\max }=341.6 \mathrm{~nm}\right)$ and $\mathrm{HOMO} \rightarrow \mathrm{LUMO}+2\left(\lambda_{\max }=297.6 \mathrm{~nm}\right)$ respectively. Moreover, the similar transition for $\mathbf{2}$ is observed and related contributions are as follows: HOMO $\rightarrow$ LUMO $\left(\lambda_{\max }=448.2 \mathrm{~nm}\right), \quad$ HOMO $\rightarrow$ LUMO+1 $\left(\lambda_{\max }=387.6 \mathrm{~nm}\right)$, HOMO$-1 \rightarrow \operatorname{LUMO}\left(\lambda_{\max }=360.9 \mathrm{~nm}\right)$, $\mathrm{HOMO} \rightarrow$ LUMO+2 $\left(\lambda_{\max }=332.8 \mathrm{~nm}\right)$ and HOMO $-1 \rightarrow$ LUMO+3 $\left(\lambda_{\max }=319.4 \mathrm{~nm}\right)$. Other calculated absorption bands in electronic spectra of complexes can be described as ILCT charge transfer that mainly due to transitions from lower MOs to higher LUMOs that four bands at 282.9 and $229.6 \mathrm{~nm}$ for compound $\mathbf{1}$ and a band at $232.3 \mathrm{~nm}$ for compound $\mathbf{2}$ is correlated to this.

Table 7

Effect of solvent and amount of catalyst (2) on the reaction of benzaldehyde with indole.

\begin{tabular}{llllll}
\hline Entry & Solvent & Mol\% $\left[\mathrm{MoO}_{2}(\mathrm{~L})(\mathrm{py})\right]$ & Temp. $\left({ }^{\circ} \mathrm{C}\right)$ & Time & Yield $(\%)$ \\
\hline 1 & $\mathrm{CHCl}_{3}$ & 1 & Reflux & $4 \mathrm{~h}$ & 0 \\
2 & $\mathrm{CH}_{3} \mathrm{OH}$ & 1 & Reflux & $4 \mathrm{~h}$ & 0 \\
3 & $\mathrm{C}_{2} \mathrm{H}_{5} \mathrm{OH}$ & 1 & Reflux & $4 \mathrm{~h}$ & 0 \\
4 & $\mathrm{TBAB}$ & 1 & 105 & $60 \mathrm{~min}$ & 50 \\
5 & $\mathrm{TBAB}$ & 1 & 110 & $40 \mathrm{~min}$ & 72 \\
6 & $\mathrm{TBAB}$ & 1 & 120 & $40 \mathrm{~min}$ & 70 \\
7 & $\mathrm{TBAB}$ & 5 & 110 & $30 \mathrm{~min}$ & 80 \\
8 & $\mathrm{TBAB}$ & 10 & 110 & $20 \mathrm{~min}$ & 91 \\
9 & $\mathrm{TBAB}$ & 15 & 110 & $20 \mathrm{~min}$ & 90 \\
\hline
\end{tabular}

\subsection{Catalytic activity}

It was of interest to us to investigate the catalytic effect of the title cis- $\mathrm{MoO}_{2}$ complexes on the electrophilic reaction of indole with aldehydes in molten tetrabutyl ammonium bromide (TBAB) (Fig. 7). In initial studies the optimization of the reaction conditions for the synthesis of bis(indolyl)methanes was investigated. Benzaldehyde $(1 \mathrm{mmol})$ and indole $(2 \mathrm{mmol})$ were chosen as model substrates. The reaction in the presence of $10 \mathrm{~mol} \%\left[\mathrm{MoO}_{2}\right.$ (L)(py)] (2) at $110^{\circ} \mathrm{C}$, in molten tetrabutyl ammonium bromide as a solvent, afforded the corresponding product in $91 \%$ yield (Table 7). With the optimized reaction conditions, we next studied the reaction of a series of aldehydes with indole. In order to show the general applicability of the method, various aldehydes were efficiently reacted with two equivalents of indole in the same conditions. As shown in Table 8, yields are good in most cases. The nature and position of the substituents on the aromatic ring have minor effect on the reaction times and the yields. Aldehydes with electron withdrawing groups such as nitro react faster than aldehydes with electron donating groups such as methoxy. On the other hand ortho substituents decrease the reaction rate to some extent. Encouraged by these successful results, we used [and $\left[\mathrm{MoO}_{2}(\mathrm{~L})(\mathrm{EtOH})\right](2)$ as a catalyst in the same conditions. $\left[\mathrm{MoO}_{2}\right.$ $(\mathrm{L})(\mathrm{EtOH})](\mathbf{1})$ gave better results compared to $\left[\mathrm{MoO}_{2}(\mathrm{~L})(\mathrm{py})\right](\mathbf{2})$.

In order to assess the efficiency of the $\mathrm{Mo}(\mathrm{VI})$ title complexes in comparison with the reported catalysts for the preparation of bis(indolyl)methane derivatives, the results of the present method were compared with the reported methods (Table 9). As it is clear from Table 3, the present method is more efficient when all terms including yields, reaction times, conditions and catalyst are taken into account. Comparison between cis- $\mathrm{MoO}_{2}$ complexes shows that (1) is more efficient than another complex. For example $\mathrm{FeCl}_{3} \cdot 6 \mathrm{H}_{2} \mathrm{O}$ gave the desired in $90 \mathrm{~min}$ while $\left[\mathrm{MoO}_{2}(\mathrm{~L})(\mathrm{py})\right]$ gave this product in $20 \mathrm{~min}$. Another factor that can be compared is the solvent. The reported method [42] used a complicated ionic liquid with high cost while our method uses a simple quaternary ammonium salt as solvent.

A tentative mechanistic interpretation to explain the formation of the observed bis(indolyl)methanes might reasonably assume a reaction path that is shown in Fig. 8. The changes of energies in the case of ( $\mathbf{1})$ for all of the reactions in the proposed mechanism were also calculated using B3LYP/DGDZVP method and shown in

Table 8

Synthesis of bis(indolyl)methanes using the $\mathrm{Mo}(\mathrm{VI})$-complexes as catalyst in molten TBAB.

\begin{tabular}{|c|c|c|c|c|c|c|c|}
\hline \multirow[t]{2}{*}{ Entry } & \multirow[t]{2}{*}{$\mathrm{Ar}$} & \multicolumn{2}{|l|}{1} & \multicolumn{2}{|l|}{2} & \multicolumn{2}{|l|}{$\mathrm{Mp}\left({ }^{\circ} \mathrm{C}\right)$} \\
\hline & & Time (min) & Yield (\%) & Time (min) & Yield (\%) & Observed & Reported [ref.] \\
\hline A & $\mathrm{C}_{6} \mathrm{H}_{5}$ & 20 & 89 & 20 & 91 & $138-140$ & $140-142[37]$ \\
\hline B & $4-\mathrm{Cl}-\mathrm{C}_{6} \mathrm{H}_{5}$ & 15 & 90 & 15 & 88 & $74-76$ & $78-80[38]$ \\
\hline $\mathrm{C}$ & $2-\mathrm{Cl}-\mathrm{C}_{6} \mathrm{H}_{5}$ & 20 & 87 & 25 & 85 & $70-73$ & $74-76[37]$ \\
\hline $\mathrm{D}$ & $3-\mathrm{NO}_{2}-\mathrm{C}_{6} \mathrm{H}_{5}$ & 12 & 88 & 15 & 88 & $258-261$ & $264-265$ [39] \\
\hline $\mathrm{E}$ & $4-\mathrm{NO}_{2}-\mathrm{C}_{6} \mathrm{H}_{5}$ & 12 & 90 & 15 & 90 & $216-218$ & $221-223[40]$ \\
\hline $\mathrm{F}$ & $4-\mathrm{CH}_{3} \mathrm{O}-\mathrm{C}_{6} \mathrm{H}_{5}$ & 25 & 86 & 30 & 83 & $187-190$ & 191-193 [40] \\
\hline G & $4-\mathrm{CH}_{3}-\mathrm{C}_{6} \mathrm{H}_{5}$ & 20 & 85 & 25 & 82 & $91-93$ & 95-97 [37] \\
\hline $\mathrm{H}$ & 2,4 -di-Cl- $\mathrm{C}_{6} \mathrm{H}_{4}$ & 20 & 83 & 25 & 84 & 99-101 & $103-105[41]$ \\
\hline
\end{tabular}

Table 9

Reaction of indole with benzaldehyde in the presence of different catalysts.

\begin{tabular}{|c|c|c|c|c|c|c|c|}
\hline Entry & Carbonyl compound & Catalyst & Cat.\% molar ratio & Solvent & Time (min) & Yield (\%) & Ref. \\
\hline \multirow[t]{5}{*}{1} & 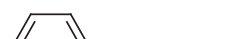 & $\mathrm{FeCl}_{3} \cdot 6 \mathrm{H}_{2} \mathrm{O}$ & 5 & [omim] $\mathrm{PF}_{6}$ & 90 & 98 & {$[42]$} \\
\hline & & $\mathrm{ZrOCl}_{2} \cdot 8 \mathrm{H}_{2} \mathrm{O}$ & 5 & Solvent-free & 40 & 84 & [43] \\
\hline & & $\mathrm{Al}\left(\mathrm{HSO}_{4}\right)_{3}$ & 100 & EtOH & 60 & 92 & [44] \\
\hline & & {$\left[\mathrm{MoO}_{2}(\mathrm{~L})(\mathrm{EtOH})\right]$} & 10 & Molten ТВAB & 20 & 89 & - \\
\hline & & {$\left[\mathrm{MoO}_{2}(\mathrm{~L})(\mathrm{py})\right]$} & 10 & Molten TBAB & 20 & 91 & - \\
\hline
\end{tabular}




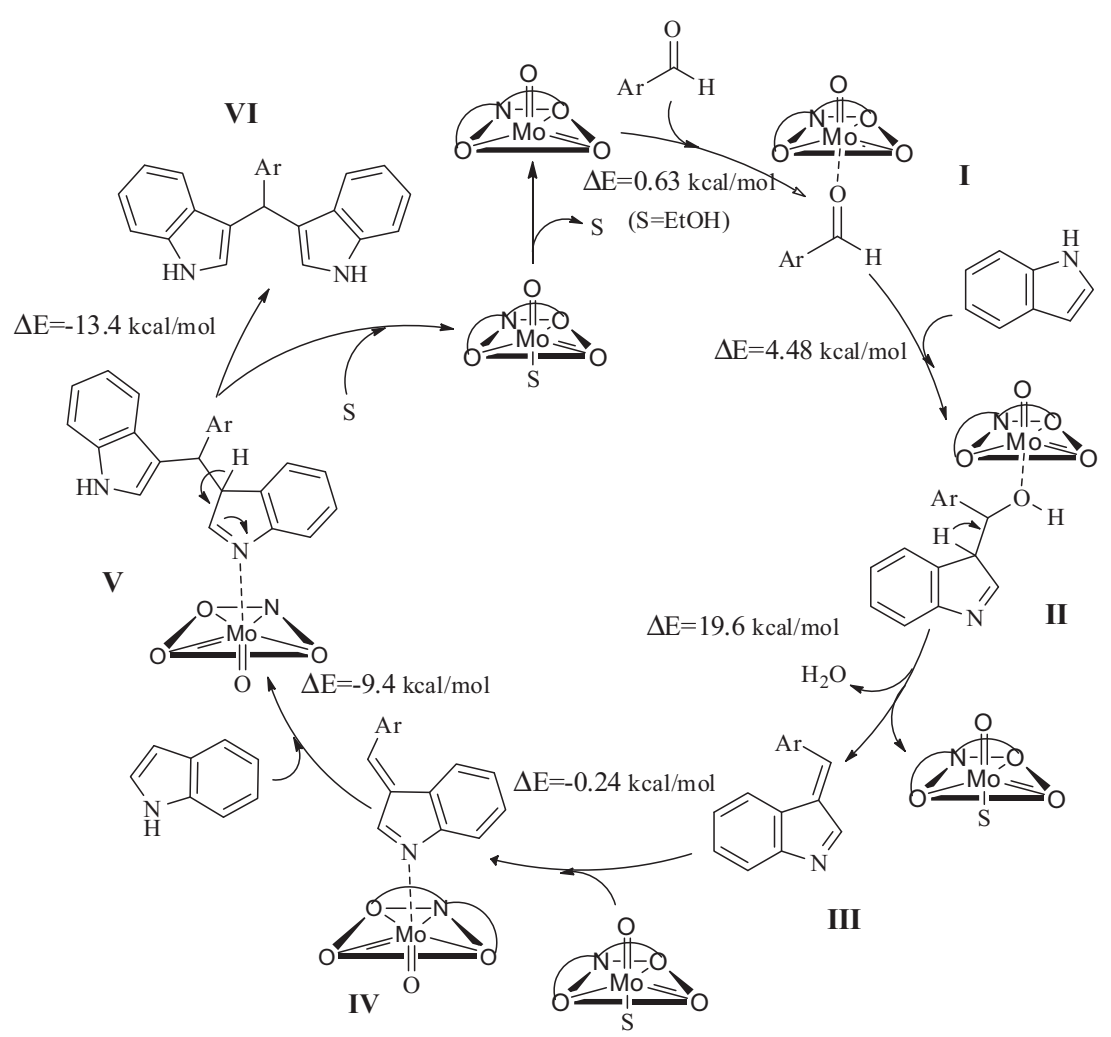

Fig. 8. The proposed mechanism for $\mathrm{Mo}(\mathrm{VI})$-complex catalyzed reaction of indole with aldehydes.

Fig. 8. It seems that in the first step; the reaction proceeds via the substituent of the aldehyde with the coordinated solvent (I). Further investigation of the potential energy surface of title reaction is needed to understand the mechanism of this substitution process which is beyond the scopes of the present work. The aldehyde molecule may be coordinated to the Mo centre of the complex and the coordinated solvent leave simultaneously the complex from the opposite direction. The computed internal energy change for this step is $+0.63 \mathrm{kcal} \mathrm{mol}^{-1}$ which indicates this substitution reaction is thermodynamically feasible. In the second step, an indole molecule is added to the compound I to form the adduct II which is $+4.48 \mathrm{kcal} \mathrm{mol}^{-1}$ more unstable than compound $\mathbf{I}+$ indole. Then, the adduct II undergoes a rearrangement reaction to produce an azafulvene adduct (III), $\mathrm{H}_{2} \mathrm{O}$ and the initial complex. This step which requires energy of $19.6 \mathrm{kcal} \mathrm{mol}^{-1}$ is the critical step from thermodynamic stand point. In the next step, Mo-complex activates the produced azafulvene molecules (IV) to form an adduct $\mathbf{V}$. The formation of adduct $\mathbf{V}$ is an exothermic process and is predicted to be thermodynamically feasible. Finally, the adduct $\mathbf{V}$ rearranges to form bis(indolyl)methane $(\mathbf{V I})$ and the initial complex.

\section{Conclusions}

Two new cis- $\mathrm{MoO}_{2}$ complexes were synthesized from the reaction of ONO tridentate Schiff base, (2-hydroxy-3-methoxybenzylidene)benzohydrazide [HL], and $\mathrm{MoO}_{2}(\mathrm{acac})_{2}$ in different solvents. All prepared compounds were characterized by elemental analysis, FT-IR, ${ }^{1} \mathrm{H}$ NMR, ${ }^{13} \mathrm{C}$ NMR and electronic spectra. The structures of the (1) and (2) were also determined by single crystal X-ray diffraction. All title complexes have octahedral geometry with positions around the central atom being occupied with donor atoms of $\mathrm{HL}$, oxido groups and $\mathrm{O} / \mathrm{N}$ donor atom of coordinated solvent. DFT calculations were done at B3LYP/DGDZVP level of theory to predict the structural geometry and interpret the electronic spectra. These complexes were used as efficient catalysts in the synthesis of bis(indolyl)methane derivatives. Results of catalytic investigations of these complexes show that (1) has more catalytic activity in compared to $(\mathbf{2})$.

\section{Acknowledgements}

This work was supported by Shahid Bahonar University of Kerman. We would like to thank the Universidade de Vigo (Spain) as well as University of Fribourg for the support in crystallography.

\section{Appendix A. Supplementary material}

Supplementary data associated with this article can be found, in the online version

\section{References}

[1] M. Sutradhar, M.V. Kirillova, M.F.C.G. da Silva, C.-M. Liu, A.J. Pombeiro, Dalton Trans. 42 (2013) 16578.

[2] P. Sathyadevi, P. Krishnamoorthy, R.R. Butorac, A.H. Cowley, N. Dharmaraj, Metallomics 4 (2012) 498.

[3] S.A. Yasrebi, H. Mobasheri, I. Sheikhshoaie, M. Rahban, Inorg. Chim. Acta 400 (2013) 222

[4] R.P. Bakale, G.N. Naik, C.V. Mangannavar, I.S. Muchchandi, I.N. Shcherbakov, C. Frampton, K.B. Gudasi, Eur. J. Med. Chem. 73 (2014) 38.

[5] S. Mukherjee, S. Chowdhury, A. Ghorai, U. Ghosh, H. Stoeckli-Evans, Polyhedron 51 (2013) 228.

[6] W.Q. Zhang, A.J. Atkin, I.J. Fairlamb, A.C. Whitwood, J.M. Lynam, Organometallics 30 (2011) 4643.

[7] M.R. Maurya, S. Dhaka, F. Avecilla, Polyhedron 67 (2014) 145.

[8] M. Bagherzadeh, M. Zare, J. Coord. Chem. 66 (2013) 2885.

[9] S.J. Ji, S.Y. Wang, Y. Zhang, T.P. Loh, Tetrahedron 60 (2004) 2051.

[10] M. Auria, Tetrahedron 47 (1991) 9225.

[11] (a) G. Babu, N. Sridhar, P.T. Perumal, Synth. Commun. 30 (2000) 1609; (b) C. Ramesh, J. Banerjee, R. Pal, B. Das, Adv. Synth. Catal. 345 (2003) 557. 
[12] (a) R. Nagarajan, P.T. Perumal, Tetrahedron 58 (2002) 1229;

(b) M. Karthik, A. Tripathi, N. Gupta, M. Palanichamy, V. Murugesan, Catal. Commun. 5 (2004) 371.

[13] J.S. Yadav, B.V.S. Reddy, C.V.S.R. Murthy, G.M. Kumar, C. Madan, Synthesis 2001 (2001) 0783.

[14] G.M. Sheldrick, sHeLX-97: Program for Crystal Structure Refinement, University of Göttinge, 1997.

[15] Bruker, SMART, SAINT, Bruker AXS Inc., Madison, Wisconsin, USA, 2007.

[16] P. McArdle, J. Appl. Crystallogr. 28 (1995) 65.

[17] G.M. Sheldrick, Acta Crystallogr. Sect. 64 (2008) 112

[18] a) A.D. Becke, J. Chem. Phys. 98 (1993) 5648; b) C. Lee, W. Yang, R.G. Parr, Phys. Rev. B 37 (1988) 785

[19] (a) N. Godbout, D.R. Salahub, J. Andzelm, E. Wimmer, Can. J. Chem. 70 (1992) 560 ;

(b) C. Sosa, J. Andzelm, B.C. Elkin, E. Wimmer, K.D. Dobbs, D.A. Dixon, J. Phys. Chem. 96 (1992) 6630.

[20] M.J. Frisch, G.W. Trucks, H.B. Schlegel, G.E. Scuseria, M.A. Robb, J.R. Cheeseman, J.A. Montgomery, T. Vreven, K.N. Kudin, J.C. Burant, J.M. Millam, S.S. Iyengar, J. Tomasi, V. Barone, B. Mennucci, M. Cossi, G. Scalmani, N. Rega, G.A. Petersson, H. Nakatsuji, M. Hada, M. Ehara, K. Toyota, R. Fukuda, J. Hasegawa, M. Ishida, T. Nakajima, Y. Honda, O. Kitao, H. Nakai, M. Klene, X. Li, J.E. Knox, H.P. Hratchian, J.B. Cross, V. Bakken, C. Adamo, J. Jaramillo, R. Gomperts, R.E. Stratmann, O. Yazyev, A.J. Austin, R. Cammi, C. Pomelli, JW. Ochterski, P.Y. Ayala, K. Morokuma, G.A. Voth, P. Salvador, J.J. Dannenberg, V.G. Zakrzewski, S. Dapprich, A.D. Daniels, M.C. Strain, O. Farkas, D.K. Malick, A.D. Rabuck, K. Raghavachari, J.B. Foresman, J.V. Ortiz, Q. Cui, A.G. Baboul, S. Clifford, J. Cioslowski, B.B. Stefanov, G. Liu, A. Liashenko, P. Piskorz, I. Komaromi, R.L. Martin, D.J. Fox, T. Keith, A. Laham, C.Y. Peng, A. Nanayakkara, M. Challacombe, P.M.W. Gill, B. Johnson, W. Chen, M.W. Wong, C. Gonzalez, J.A. Pople, Gaussian 03, Revision C.02, Gaussian Inc., Wallingford, CT, 2004.

[21] N.M. O’Boyle, A.L. Tenderholt, K.M. Langner, J. Comput. Chem. 29 (2008) 839.

[22] I. Sheikhshoaie, S.Y. Ebrahimipour, M. Sheikhshoaie, H.A. Rudbari, M. Khaleghi, G. Bruno, Spectrochim. Acta, Part A Mol. Biomol. Spectrosc. 124 (2014) 548.

[23] (a) S.Y. Ebrahimipour, J.T. Mague, A. Akbari, R. Takjoo, J. Mol. Struct. 1028 (2012) 148;

(b) S.Y. Ebrahimipour, M. Abaszadeh, J. Castro, M. Seifi, Polyhedron 79 (2014) 138.
[24] (a) R. Takjoo, J.T. Mague, A. Akbari, S.Y. Ebrahimipour, J. Coord. Chem. 66 (2013) 2852;

(b) R. Takjoo, A. Akbari, S.Y. Ebrahimipour, H. Amiri Rrudbari, G. Brunò, C. R Chim 17 (2014) 1144.

[25] R. Takjoo, A. Akbari, M. Ahmadi, H. Amiri Rudbari, G. Bruno, Polyhedron 55 (2013) 225.

[26] S. Alghool, C. Slebodnick, Polyhedron 67 (2014) 11.

[27] S. Pasayat, S.P. Dash, S. Roy, R. Dinda, S. Dhaka, M.R. Maurya, W. Kaminsky, Y.P. Patil, M. Nethaji, Polyhedron 67 (2014) 1.

[28] H.H. Monfared, S. Alavi, R. Bikas, M. Vahedpour, P. Mayer, Polyhedron 29 (2010) 3355.

[29] A.L. Spek, Acta Crystallogr., Sect. 65 (2009) 148.

[30] R. Dinda, P. Sengupta, S. Ghosh, William S. Sheldrick, Eur. J. Inorg. Chem. 2003 (2003) 363.

[31] V. Vrdoljak, M. Cindri, D. Matkovic-Calogovi, B. Prugovecki, P. Novak, B. Kamenar, Z. Anorg, Allg. Chem. 631 (2005) 928.

[32] M. Bagherzadeh, M.M. Haghdoost, A. Ghanbarpour, M. Amini, H.R. Khavasi, E. Payab, A. Ellern, L.K. Woo, Inorg. Chim. Acta 411 (2014) 61.

[33] B. Cordero, V. Gomez, A.E. Platero-Prats, M. Reves, J. Echeverria, E. Cremades, F. Barragan, S. Alvarez, Dalton Trans. (2008) 2832.

[34] F.H. Allen, Acta Crystallogr., Sect. 58 (2002) 380.

[35] S. Gupta, A.K. Barik, S. Pal, A. Hazra, S. Roy, R.J. Butcher, S.K. Kar, Polyhedron 26 (2007) 133.

[36] H.H. Monfared, R. Bikas, P. Mahboubi-Anarjan, A.J. Blake, V. Lippolis, N.B. Arslan, C. Kazak, Polyhedron 69 (2014) 90

[37] A. Hasaninejad, Arkivoc 2007 (2007) 39.

[38] M.L. Deb, P.J. Bhuyan, Tetrahedron Lett. 47 (2006) 1441.

[39] S. Mishra, R. Ghosh, Indian J. Chem. 50B (2011) 1630.

[40] S.A. Sadaphal, K.F. Shelke, S.S. Sonar, M.S. Shingare, Cent. Eur. J. Chem. 6 (2008) 622.

[41] R. Ghorbani-Vaghei, H. Veisi, H. Keypour, A.A. Dehghani-Firouzabadi, Mol. Divers. 14 (2010) 87

[42] S.J. Ji, M.F. Zhou, D.G. Gu, Z.Q. Jiang, T.P. Loh, Eur. J. Org. Chem. 2004 (2004) 1584.

[43] H. Firouzabadi, N. Iranpoor, M. Jafarpour, A. Ghaderi, J. Mol. Catal. A: Chem. 253 (2006) 249

[44] K. Niknam, M.A. Zolfigol, T. Sadabadi, A. Nejati, J. Iran. Chem. Soc. 3 (2006) 318. 